\author{
JELENA D. RAJOVIĆ ${ }^{1}$ \\ TECHNICAL COLLEGE OF APPLIED SCIENCES \\ UROŠEVAC WITH TEMPORARY SEAT IN LEPOSAVIĆ \\ MILICA M. SPASIĆ-STOJKOVIĆ ${ }^{2}$ \\ ACADEMY OF VOCATIONAL STUdIES, LESKOVAC \\ DEPARTMENT OF BUSINESS STUDIES, BLACE
}

\title{
ENGLISH NOUN+NOUN SYNTACTIC STRUCTURES IN ENGLISH FOR SPECIFIC PURPOSES AND THEIR SERBIAN EQUIVALENTS
}

\begin{abstract}
The purpose of this study is to investigate if there is a structure agreement between syntactic structures consisting of two nouns $[N+N]$ in English for Occupational Health and Safety and their Serbian equivalents. After narrowing down the results of the research to approximately five thousand examples and ordering them by frequency of appearance in the corpus, a sample of about one hundred and seventy items was extracted and translated into Serbian. The analysis shows that there are three main types of Serbian translation equivalents but none of them are structurally identical to English noun + noun structures.
\end{abstract}

KEYWORDS: English for specific purposes, syntactic structures, Occupational health and safety, Serbian language, English language.

gvozdena2001@yahoo.com

aidnimspasic@yahoo.com

This paper was submitted on July $22^{\text {th }}, 2020$ and accepted for publication at the meeting of the Editorial Board held on September $25^{\text {th }}, 2020$. 


\section{INTRODUCTION}

In the last fifty years, great attention has been given to English for Specific Purposes (ESP) due to the fact that the majority of inventions and innovations emerging in science and technology comes from the English speaking countries. This has a direct impact on the use of specialized terminology in teaching a foreign language for occupational purposes. ESP has become the international means of communication among experts and scientists and almost all specialized literature has been published in the English language. The language-terminology of Safety Engineering is not an exception. The World Health Organization (WHO) offers the following definition: "Occupational health deals with all aspects of health and safety in the workplace and has a strong focus on primary prevention of hazards". It implies that Safety engineers, apart from professional skills, also need to have a fundamental knowledge of other sciences and must be familiar with terminology closely related to their field of interest, depending on what their job description particularly requires (The American Society of Safety Engineers, ANSI/ASSE Z590.2-2003 Criteria for Establishing the Scope and Functions of the Professional Safety Position). This means that the Occupational Health and Safety terminology is complex and versatile.

In this paper, we are dealing with the vocabulary used in the field of Occupational Health and Safety. Good command of professional vocabulary is of great importance both for safety engineers and for understanding the latest developments in this area. Special attention is given to English $\mathrm{N}+\mathrm{N}$ syntactic structures in the field of Occupational Health and Safety and their equivalents in the Serbian language. At present, there is no English-Serbian or vice versa specialized dictionary dealing with vocabulary and terms of Occupational health and safety. The aim of this paper is to determine how English N + N syntactic structures correspond to Serbian translation equivalents and whether there is a structure agreement. According to Algeo (1991), the most frequent word formation process is compounding, out of which $68 \%$ are the new words, whereas $90 \%$ of these new compounds actually are noun compounds.

The corpus was extracted from various websites of companies specialized for Occupational health and safety and professional literature. 
IMPORTANCE OF ENGLISH FOR SPECIFIC PURPOSES

English for specific purposes is a term that appeared in the 1960s. ESP is focused on context. The English language taught within the scope of ESP is intended to meet learners' needs regarding the particular field of interest related to occupation or profession, and is applicable in the employment context.

According to Mackay and Mountford (1978, p. 2), ESP is focused on the teaching of English for a practical purpose, meaning that the teaching of English for specific purposes should be focused on achieving of those language skills that will enable learners to use English in their future occupations more efficiently.

Hutchinson and Waters (1987, p. 19) postulate that ESP does not present a specific kind of language or teaching methodology and does not require a particular type of teaching material. Instead, it is an approach to language learning "aimed to address the learners' needs". This means that content and methods of such language teaching are focused on learners' reasons for learning, and thus cover topics that will be used for specific purposes.

The similar opinion about learning English in general is given by Robinson (1991, p. 2), who states that students learn English "not because they are interested in the English language or English culture as such, but because they need English for study or work purposes". This means that students who learn English are motivated by different reasons: to be able to read specialized texts, to read textbooks written in English relevant to their field of expertise or to use it in their future occupation or at a workplace.

When outlining the major features of ESP, Dudley-Evans and St. John $(1998$, p. 4), argue that there are two types of characteristics of ESP, absolute and variable. According to them, absolute characteristics are: "a) ESP is defined to meet the specific needs of the learners; b) ESP makes use of underlying methodology and activities of the discipline it serves; c) ESP is centred on the language (grammar, lexis, and register), skills, discourse and genre appropriate to these activities". Variable characteristics are: "a) ESP may be related to or designed for specific disciplines; b) ESP may use, in specific teaching situations, a different methodology from that of General English; c) ESP is likely to be designed for adult learners, either at a tertiary level institution or in a professional work situation. It could, however, be for learners at secondary school level; d) ESP is 
generally designed for intermediate or advanced students. Most ESP courses assume some basic knowledge of the language systems, but it can be used with beginners".

Basturkmen (2006, p. 18) asserts that, "in ESP language is learnt not for its own sake or for the sake of gaining a general education, but to smooth the path to entry or greater linguistic efficiency in academic, professional or workplace environments". This means that the ESP focuses on the needs of language learners typical for a specific field of occupation or workplace.

ESP is not limited only to those learners who plan their future careers but is also intended for those who are already employed and who perform professional tasks in the scenario that requires the use of the English language.

In this paper we are focused on the terminology of occupational safety and health in a sense that "environmental and occupational health is not a single topic, but rather a colourful, complex, and diversified range of interrelated subjects including all of the basic sciences, engineering, computer science, government, disease, injury identification, prevention, and control" (Herman, vi: 2013) .

\section{TYPES OF NOUN +NOUN STRUCTURES IN ENGLISH LANGUAGE}

Noun + Noun structures are very important in ESP, since this is a common way of creating new terms and they represent two-thirds of all technical terms (Cabre, 1999, p. 122). A large number of these structures occur in textbooks of social and natural science courses and engineering textbooks (Cohen et al. 1988; Ward, 2007; Wasuntarasophit, 2008). The frequent usage on $\mathrm{N}+\mathrm{N}$ structures has been proved through various studies on ESP covering different fields (Salager-Meyer, 1984; Cohen et al. 1988; Lauer, 1995). This frequent usage implies that special attention should be given to the role of $\mathrm{N}$ + N structures in ESP. These structures are composed of two nouns, where the first one is premodifier and the second one is a head noun. There is no additional element between these two nouns that binds them.

This type of structures differs from other types of structures (Adj $+\mathrm{N}$; V + N, etc.) in English language in that that it "allows encoding complex concepts through an extremely compressed format, mak- 
ing use of as little space as language enables to" (Fernández-Domínguez, 2010). This implies that in $\mathrm{N}+\mathrm{N}$ structures, the head is the main category and premodifier or first noun outlines the head, that is, distinguishes it from others in the same category. Noun + Noun structures express the relation between two nouns, but this relation has not been specified yet and may have different characteristics (for example, emergency procedure meaning procedure in emergency situations; work overload meaning overload of work; explosion protection meaning protection from explosion, etc.).

Generally speaking, there are three different approaches that deal with the relation of nouns in $\mathrm{N}+\mathrm{N}$ structures. The first group of approaches usually takes into account the fixed types of relations and describes these structures based on well-established principles. The second group uses English prepositions to describe these relations. The third group of approaches interprets the relation of nouns in $\mathrm{N}+\mathrm{N}$ structures by using paraphrasing. This would produce interpretations such as "exit used in the cases of emergency situations" for emergency exit.

However, it seems that the main problem with Noun + Noun structures relates to two issues: the first one concerning their internal semantic configuration and the second that their formal appearance is identical with that of some syntactic structures, in cases where noun modifies another noun.

We may say that there are two categories of Noun + Noun structures in the English language, the morphological and syntactic, whereas the former one accounts for compounds and the latter for syntactic structures.

However, morphology is still trying to determine where $\mathrm{N}+\mathrm{N}$ structures belong, to morphology or syntax, since agreement on this issue is still in dispute. Many researchers have tried to answer this question and Bauer (1998) divides these researchers into two groups, based on their views on the issue: splitters and lumpers. The splitters in $\mathrm{N}+\mathrm{N}$ structures, distinguish two classes: syntactic structures consisting of nouns with nominal modifiers, and compounds. However, they do not always set the proper criteria for such classification. Lumpers, on the other hand, see only one class class of compounds, and correlate their classification with a difference in stress. Further, Bauer (1998) proposes six possible criteria to distinguish between syntactic structures and compounds: Compounds are listed; Compounds are written as a single word; Com- 
pounds have fore-stress; The first element in a compound is syntactically isolated; Compounds do not permit co-ordination and the head in a phrase can be replaced by one.

Huddleston and Pullum (2002) use the following criteria to illustrate differences between the two structure types: orthography morphological compounds are written as a single word (greenhouse, newspaper) and syntactic structures are written as word sequences (green house, quality paper); stress - morphological compounds are pronounced with the main stress on the first component and syntactic structures are pronounced with the stress on the second component of $\mathrm{N}+\mathrm{N}$ structure, and modification test morphological compounds exclude modification of the first component while syntactic structures "allow a very wide range of modifications" (Huddleston and Pullum. 2002, p. 1644). Even though they state that both syntactic test and non-syntactic criteria have certain deficiencies, they still prefer syntactic tests to non-syntactic criteria: "The correlation between these criteria and the syntactic tests of coordination and modification is, however, very imperfect, and since we are concerned with the delimitation of a syntactic structure we will naturally give precedence to the syntactic tests in the many cases of divergent results" (Huddleston and Pullum, 2002, p. 451).

Taking into account the nature of $\mathrm{N}+\mathrm{N}$ structures, these structures in most cases share both morphological and syntactic properties. According to Moon (1997, p. 43): "This sequence of words semantically and/or syntactically forms a meaningful and inseparable unit".

\section{NATURE OF NOUN + NOUN STRUCTURES}

There have been several attempts to classify noun + noun structures. According to Quirk $(1985,1332)$, Noun + Noun combinations, both syntactic structures and compounds, may be paraphrased by a preposition, and he arranges them into groups expressing sourceresult (metal sheet/sheet of metal); part - whole (clay soil/soil with clay); place (top drawer/drawer at the top); time (morning train/ train in the morning) and whole-part (board member/member of the board).

Biber et al. (1999) assert that Noun + Noun structures contain only content words and thus represent two "opposite extremes of 
communicative priority" (Biber et al. 1999, pp. 589-591). They classify them into 15 basic groups, based on the relation between two nouns in the structure (N2 presents head noun and N1 premodifying noun) : "Composition - N2 is made from N1; N2 consist of N1, (e.g. glass windows $=$ windows made of glass); Purpose $-\mathrm{N} 2$ is for the purpose of N1; N2 is used for N1, (e.g. safety device = device used for safety); Identity - N2 has the same referent as N1, but classifies it in terms of different attributes (e.g. woman firefighter $=$ firefighter who is woman); Content - N2 is about N1; N2 deals with $\mathrm{N} 1$, (e.g. emergency plan = plan relating to emergency situations); Source - N2 is from N1, (e.g. computer printout = printout that comes from computer); Objective type $1-\mathrm{N} 1$ is the object of the processes described in N2, or of the action performed by the agent described in N2 (e.g. ear protector = protects ear); Objective type 2 - N2 is the object of the processes described in N1, (e.g. safety engineer - engineer responsible for the safety); Subjective type 1-N1 is the subject of the process described in N2; N2 is nominalized form an intransitive verb (e.g. disability assessment); Subjective type 2 $\mathrm{N} 2$ is the subject of the processes described in N1 (e.g labour force a force engaged in labour); Time: $\mathrm{N} 2$ is found at the time given by $\mathrm{N} 1$ (e.g. winter conditions); Location type $1-\mathrm{N} 2$ is found or takes place at the location given by $\mathrm{N} 1$ (e.g. mine ventilation); Location type $2-\mathrm{N} 1$ is found at the location given by N2 (e.g. inhalation room); Institution - N2 identifies an institution for N1 (e.g. labour inspectorate); Partitive - N2 identifies parts of N1 (e.g. risk factors); Specialization - N1 identifies an area of specialization for the person or occupation given in N2, N2 is animate (e.g. employer representative)" (Biber et al. 1999, pp. 589-591). This classification, according to same authors, is not limited by the categories, i.e. some $\mathrm{N}+\mathrm{N}$ structures can belong to more than one category and there are noun + noun structures that do not belong to any of the given categories. Moreover, there are $\mathrm{N}+\mathrm{N}$ structures that can have meaning relations that are different from these described here.

The classification of Noun + Noun structures can be made based on different criteria. However, none of these classifications are final, nor can we say with certainty which is the most accurate one. The list is quite long and versatile, and there is no ultimate classification. This partially depends on the nature of the English language and partially on how the researchers perceive this issue and what classification criteria they use. 


\section{ANALYSIS AND RESULTS}

The corpus was excerpted from Occupational Safety and Health Glossary (The International Labour Organisation), Glossary of Occupational Health \& Safety Terms (Industrial Accident Prevention Association), The Environmental and Occupational Health \& Safety terminology website (EOHS), Dictionary of Occupational Health and Safety Terms, Glossary for Basic Occupational Safety and Health (van Dijk et al., 2011), and from Engleski jezik za studente Fakulteta zaštite na radu (Tošić, 1992). The targets of the study were English N + N syntactic structures which were later translated into Serbian for the purpose of this paper in order to provide their equivalents. After narrowing down the results of the search to approximately five thousand examples and ordering them by the frequency of appearance in the corpus, a sample of about one hundred and seventy items (among the most frequent ones) was extracted and translated into Serbian. The translated structures were grouped into categories, which are based on the nature of Serbian translation equivalents ${ }^{3}$.

\begin{tabular}{|c|c|}
\hline ENGLISH N+N SYNTACTIC STRUCTURES & $\begin{array}{c}\text { SERBIAN TRANSLATION EQUIVALENT } \\
\text { (N+NOUN IN GENITIVE) }\end{array}$ \\
\hline accident frequency & učestalost nezgoda \\
\hline air humidity & vlažnost vazduha \\
\hline disability assessment & procena invaliditeta \\
\hline exposure rate & stepen izloženosti \\
\hline fatigue prevention & prevencija Zamora \\
\hline hearing damage & oštećenje sluha \\
\hline injury analysis & analiza povrede \\
\hline labour inspector & inspektor rada \\
\hline risk assessment & procena rizika \\
\hline
\end{tabular}

TABLE 1: ENGLISH N + N SYNTACTIC STRUCTURES AND THEIR SERBIAN EQUIVALENTS ( $\mathrm{N}+$ NOUN IN GENITIVE)

3 Due to the limited scope of the paper, only ten examples from the analysed corpus are presented. The complete list of the analysed corpus is given in the Appendix. 
TABLE 1: $\quad$ ENGLISH $\mathrm{N}+\mathrm{N}$ SYNTACTIC STRUCTURES AND THEIR SERBIAN EQUIVALENTS $(\mathrm{N}+$ NOUN IN GENITIVE)

From the examples provided in Table 1 we can see that Serbian equivalents include $\mathrm{N}+\mathrm{N}$ structures, where the second $\mathrm{N}$ is inflected. The second noun is modified and marked by Genitive case and the first noun is a head noun.

It may appear that Serbian translation equivalents are structurally close to English corresponding items since in both cases we have $\mathrm{N}+\mathrm{N}$ pattern. However, they are not. There are two major differences between English $\mathrm{N}+\mathrm{N}$ structures and Serbian $\mathrm{N}+\mathrm{N}$ structures: the modifying noun has a different case-marking and the head-modifier ordering is different (Dimković-Telebaković, 2014):

a.

$2 \quad 1 \quad 112$

risk assessment $=$ procena rizika

\begin{tabular}{|l|l|}
\hline \multicolumn{1}{|c|}{ ENGLISH N+N SYNTACTIC STRUCTURES } & SERBIAN TRANSLATION EQUIVALENT (ADJ+N) \\
\hline fire alarm & protivpožarni alarm \\
\hline first aid & prva pomoć \\
\hline health insurance & zdravstveno osiguranje \\
\hline mental health & mentalno zdravlje \\
\hline safety clothing & zaštitna odeća \\
\hline safety footwear & zaštitna obuća \\
\hline safety glass & sigurnosno staklo \\
\hline safety glasses & zaštitne naočare \\
\hline shift work & smenski rad \\
\hline work overload & radno preopterećenje \\
\hline
\end{tabular}

TABle 2: $\quad$ ENGLISH $\mathrm{N}+\mathrm{N}$ SYNTACTIC STRUCTURES AND THEIR SERBIAN EQUIVALENTS (ADJ + N)

The second group of Serbian equivalents consists of adjective + noun structure (Table 2). Here, the adjective is premodifying the noun, and thus in this group Serbian equivalents are not structurally equivalent to those in English, since the modifier belongs to a different word class category. Here we have English noun + noun structure $=$ Serbian adjective + noun structure. 
The third group of Serbian equivalents has the pattern $\mathrm{N}+$ Prepositional Phrase (PP) and is presented in Table 3.

\begin{tabular}{||l|l|}
\hline \multicolumn{1}{|c|}{ ENGLISH N+N SYNTACTIC STRUCTURES } & \multicolumn{1}{c|}{ SERBIAN TRANSLATION EQUIVALENT (N+PP) } \\
\hline accident risk & rizik od nezgode \\
\hline explosion protection & zaštita od eksplozije \\
\hline fire risks & rizici od požara \\
\hline welding mask & maska za zavarivanje \\
\hline work accident & nezgoda na radu \\
\hline workplace conditions & uslovi na radnom mestu \\
\hline workplace hazards & opasnosti na radnom mestu \\
\hline workplace injury & povreda na radnom mestu \\
\hline workplace stress & stres na radu \\
\hline \hline
\end{tabular}

TABLE 3: ENGLISH N + N SYNTACTIC STRUCTURES AND THEIR SERBIAN TRANSLATION EQUIVALENTS $(\mathrm{N}+\mathrm{PP})$

From the examples presented in Table 3, we can see that Serbian equivalents can have elements which do not appear in English $\mathrm{N}+\mathrm{N}$ structure, and in this case it is a prepositional phrase. Based on Dimković-Telebaković (2014), this can be presented in a form of patterns which in Serbian have inserted elements, prepositions: $231 \rightarrow 123:$

b.

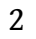

$$
\begin{aligned}
& \begin{array}{lllll}
3 & 1 & 1 & 2 & 3
\end{array} \\
& \text { welding mask = maska za zavarivanje }
\end{aligned}
$$

c.

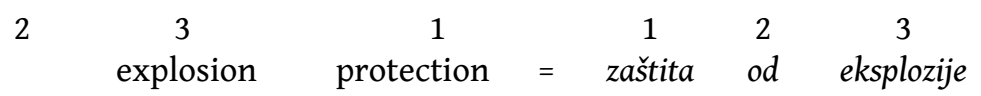

Apart from these corresponding structures we addressed in Tables 1,2 and 3, we also found some complex Serbian structures that correspond to English N + N structures: noun + noun + noun in Genitive (accident probability - verovatnoća nastanka nezgode); noun + adjective + noun (emission spectrometry - spektrometrija izduvnih gasova; incident investigation - istraga nesretnog slučaja; workplace inspection - inspekcija radnog mesta; health standards standardi zdravstvene zaštite). 
d.

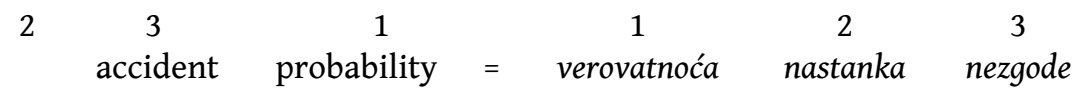

e.

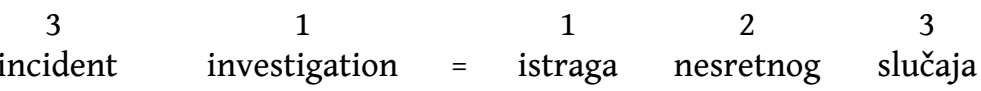

Patterns $d$ and $e$ corresponds to $\mathrm{N}+\mathrm{N}+\mathrm{N}$ and $\mathrm{N}+\mathrm{Adj}+\mathrm{N}$ structures, respectively. Patterns $d$ and $e$ in English do not contain all the elements, which are present in Serbian with $231 \rightarrow 123$ pattern.

Based on the analysis we conducted in this paper, we may conclude that out of 170 examples of English $\mathrm{N}+\mathrm{N}$ syntactic structures taken from the corpus of about five thousand examples, the $61.7 \%$ Serbian translation equivalents belong to the largest group noun + noun in Genitive; $9.4 \%$ belongs to the group adjective + noun, and the $22.3 \%$ to the group noun + prepositional phrase. While investigating the selected corpus, we found only a few examples of English structures where Serbian translation equivalents were consisting of only one word, $\mathrm{N}+\mathrm{N} \rightarrow \mathrm{N}$ : work capacity $\rightarrow$ produktivnost; shock absorber $\rightarrow$ amortizer; construction site $\rightarrow$ gradilište.

CONCLUSION The aim of this paper was to analyse the English noun + noun syntactic structures in the field of Occupational Health and Safety and their Serbian equivalents. In Serbia, Occupational Health and Safety is a field that has gained in importance in recent years due to the need to meet European standards. In order to meet the ESP language requirements, specialized terms should be concise and accurate. Terms defined in such a way express the precise meaning of concepts, and when one concept is represented by one word the brevity is achieved (Dimković-Telebaković, 2014).

Based on the conducted analysis we may conclude that there are three main types of Serbian translation equivalents. The first group includes structures consisting of two nouns (English $\mathrm{N}+\mathrm{N} \rightarrow$ Serbian N + Noun in Genitive) where the second noun is in genitive, which is also the largest group. The first noun has the status of a head noun, the second noun is a modifier and it is marked by the genitive case, e.g. fatigue prevention- prevencija zamora. When it comes to structural correlation, we can conclude that this group of Serbian translation equivalents is not equivalent to English $\mathrm{N}+\mathrm{N}$ structures, although it may appear as such. This is due to their 
structural non-equivalence and different case-marking of the modifying noun and different head modifier ordering.

The second group is adjective + noun translation equivalent (English $\mathrm{N}+\mathrm{N} \rightarrow$ Serbian Adj $+\mathrm{N}$ ). Here, the adjective premodifies the noun and both of them are marked, e.g. mental fatigue - mentalni zamor. Furthermore, structurally English $\mathrm{N}+\mathrm{N}$ structures and Serbian translation equivalents do not match since they consist of an adjective and a noun.

The third group, $\mathrm{N}+\mathrm{PP}$, translation equivalent (English $\mathrm{N}+\mathrm{N} \rightarrow$ Serbian N + PP) shows that Serbian equivalents have some elements which do not appear in English structures, and in this case it is a prepositional phrase, e.g. work accident $\rightarrow$ nezgoda na radu.

And finally, we also presented some complex Serbia structures that corresponds to English $\mathrm{N}+\mathrm{N}$ structures, which also are not equivalents to English structures because they have some elements which do not appear in English structures $(\mathrm{N}+\operatorname{Adj}+\mathrm{N}, \mathrm{N}+\mathrm{N}+\mathrm{N})$.

It is due to the diverse nature of Serbian and English that the differences among English $\mathrm{N}+\mathrm{N}$ syntactic structures and their Serbian equivalents exist. Serbian language does not tolerate two nominative - marked nouns in a sequence, and thus none of the Serbian translation equivalents are structurally identical to English structures.

The paper should help to better comprehend English $\mathrm{N}+\mathrm{N}$ syntactic structures in the field of Occupational Health and Safety and how they are translated into Serbian not only in a theoretical, but in a practical aspect too, while future research should be done on a wider corpus that would offer a more detailed insight into other English syntactic structures in the field of Occupational Health and Safety and their translation (and non-translation) equivalents.

REFERENCES Algeo, J. (1991). Fifty Years Among the New Words. Cambridge: Cambridge University Press.

Basturkmen, H. (2006). Ideas and Options in English for Specific Purposes. London and New jersey: ESL and Applied Linguistic Professional Series: Eli Hinkel, Edition, pp. 18.

Bauer, Laurie. (1998). When is a sequence of two nouns a compound in English?. English Language and Linguistics. 2. 65 - 86. 10.1017/S1360674300000 691.

Biber, D. et al., (1999). Longman Grammar of Spoken and Written English. London: Longman. pp. 589-591 
Cabré, M. T. (1999). Terminology: Theory, methods, and applications (Vol. 1). John Benjamin's Publishing.

Cohen, A., Glasman, H., Rosenbaum-Cohen, P., Ferrara, J., \& Fine, J. (1988). Reading English for specialized purposes: Discourse analysis and the use of student informants. In P. Carrell, J. Devine \& D. Eskey (Eds.), Interactive approaches to second language reading (pp.152-167). Cambridge: Cambridge University Press.

Dictionary of Occupational Health and Safety Terms. Available at https://www. tdi.texas.gov/pubs/videoresource/englishspani.pdf. Accessed 27.05.2018.

Dimković-Telebaković, G. (2014). The Dynamics Of English Terminological Compound Lexemes And Their Serbian Equivalents, Romanian Journal of English Studies, De Gruyter Open, Volume 11, issue 1, pp. 9-20.

Dudley, E., \& Johns, St. (1998). Developments in ESP a Multi-Disciplinary Approach. Cambridge: Cambridge University Press.

Fernández-Domínguez, J. (2010). N+N compounding in English: Semantic categories and the weight of modifiers. Brno Studies in English. 36. pp. 47-76.

Herman, K. (2013). Illustrated Dictionary and resource Directory of Environmental Health \& Occupational Safety. Second edition, CRC Press, Boca Raton: Lewis Publishers, New York.

Hutchinson, T. \& Waters, A. (1987). English for Specific Purposes: A Learning-centred approach, Cambridge University Press., Cambridge

Huddleston, R. \& Pullum, K. G. (2002). The Cambridge Grammar of the English Language. Cambridge: Cambridge University Press.

Industrial Accident Prevention Association (IAPA) Website, (2018). Glossary of Occupational Health \& Safety Terms. Available at http://www.iapa.ca/pdf/ iapa_glossary.pdf. Accessed 27.05.2018.

Lauer, M. (1995). Designing statistical language learners: experiments on noun compounds. Macquarie University, Australia.

Mackay, R. and Mountford, A. (1978) English for Specific Purposes: A case Study Approach. London: Longman.

Moon, R. (1997). Vocabulary Connection: multi-word items in English. In N. Schmitt \& M. McCarthy (Eds.), Vocabulary: Description, Acquisition and Pedagogy (pp. 40 - 63). Cambridge: Cambridge University Press.

Quirk, R., Sidney, G., Geoffrey, L., \& Jan, S. (1985). A Comprehensive Grammar of the English Language. London: Longman.

Robinson, P (1991) ESP today.UK: Prentice Hall International ltd.

Salager-Meyer, F. (1984). Compound nominal phrases in scientific-technical literature: proportion and rationale. In A. K. Pugh \& J. M. Ulijin (Eds.), Reading for professional purposes - studies and practices in native and foreign languages (pp. 138-149). London: Heinemann. 
The American Society of Safety engineers, ANSI/ASSE Z590.2-2003 Criteria for Establishing the Scope and Functions of the Professional Safety Position Accessed 12. 05. 2018 at https://www.coss.net/docs/cosm/z590.pdf. .

The Environmental and Occupational Health \& Safety terminology website (EOHS), (2018). Available at https://www.osha.gov/dcsp/compliance_ass istance/spanish/osha_general_terms_ensp.html. Accessed 01.06.2018.

The International Labour Organisation Website, (2018). Occupational Safety and Health Glossary. Available at

http://www.ilo.org/safework/info/publications/WCMS_113126/

lang--en/index.htm. Accessed 01.06.2018.

Tošić, J. (1992). Engleski jezik za studente Fakulteta zaštite na radu, Izdavačka jedinica Univerziteta u Nišu, Niš.

Van Dijk, F., Varekamp, I., Radon, K., \& Parra, M. (2011). Glossary for Basic Occupational Safety and Health. Available at https://ldoh.net/wp-content/uploads/2014/10/Glossary-for-basic-occupational-safe-

ty-and-health-English-17-11-2014.pdf. 27.05.2018.

Ward, J. (2007). Collocation and technicality in EAP engineering. Journal of English for Academic Purposes, 6(1), 18-35.

Wasuntarasophit, S. (2008). Technical and Academic Vocabulary in Electrical Engineering Textbooks. Suranaree University of Technology, Nakhon Ratchasima.

WPRO | Occupational health Available at http://www.wpro.who.int/topics/occupational_health/en/. Accessed 12.05.2018.

\section{APPENDIX}

\begin{tabular}{|l|l|}
\hline \multicolumn{1}{|c|}{ ENGLISH N + N SYNTACTIC STRUCTURES } & \multicolumn{1}{c|}{$\begin{array}{c}\text { SERBIAN TRANSLATION EQUIVALENT } \\
(\mathrm{N}+\text { NOUN IN GENITIVE })\end{array}$} \\
\hline absorption coefficient & koeficijent apsorpcije \\
\hline accident cause & uzrok nezgode \\
\hline accident frequency & učestalost nezgoda \\
\hline accident investigation & istraga nezgode \\
\hline accident location & lokacija nezgode \\
\hline accident severity & ozbiljnost nezgode \\
\hline accident victim & žrtva nezgode \\
\hline air contaminant & zagađivač vazduha \\
\hline \hline
\end{tabular}

TABLE 4: ENGLISH N + N SYNTACTIC STRUCTURES AND THEIR SERBIAN TRANSLATION EQUIVALENTS ( $\mathrm{N}+$ Noun IN GENITIVE) 


\begin{tabular}{|c|c|}
\hline air humidity & vlažnost vazduha \\
\hline air pollution & zagađenje vazduha \\
\hline air quality & kvalitet vazduha \\
\hline air temperature & temperatura vazduha \\
\hline alarm system & sistem upozorenja \\
\hline alcohol consumption & konzumiranje alkohola \\
\hline back injury & povreda leđa \\
\hline body parts & delovi tela \\
\hline colour identification & identifikacija boje \\
\hline contamination level & nivo zagađenja \\
\hline danger sign & znak opasnosti \\
\hline danger zone & zona opasnosti \\
\hline detonation velocity & brzina detonacije \\
\hline disability assessment & procena invaliditeta \\
\hline dust collector & sakupljač prašine \\
\hline dust concentration & koncentracija prašine \\
\hline dust sample & uzorak prašine \\
\hline employee representative & predstavnik zaposlenih \\
\hline employee training & obuka zaposlenih \\
\hline employer representative & predstavnik poslodavca \\
\hline energy sources & izvori energije \\
\hline evaporation rate & stopa isparavanja \\
\hline explosion detector & detektor eksplozije \\
\hline explosion prevention & prevencija eksplozije \\
\hline exposure maps & mape izloženosti \\
\hline exposure rate & stopa izloženosti \\
\hline eye damage & oštećenje oka \\
\hline eye diseases & bolesti oka \\
\hline eye injury & povreda oka \\
\hline eye protection & zaštita oka \\
\hline fatigue prevention & prevencija zamora \\
\hline
\end{tabular}

TABLE 4: $\quad$ ENGLISH $\mathrm{N}+\mathrm{N}$ SYNTACTIC STRUCTURES AND THEIR SERBIAN TRANSLATION EQUIVALENTS $(\mathrm{N}+$ Noun In GeNITIVE) 


\section{Collection of Papers of the Faculty of Philosophy L(3)/2020}

\begin{tabular}{|c|c|}
\hline fire prevention & prevencija požara \\
\hline friction noise & buka trenja \\
\hline grounding system & sistem uzemljenja \\
\hline hazard survey & ispitivanje opasnosti \\
\hline hazard symbol & simbol opasnosti \\
\hline hearing damage & oštećenje sluha \\
\hline hearing disturbances & poremećaj sluha \\
\hline hearing level & nivo sluha \\
\hline hearing loss & gubitak sluha \\
\hline heart damage & oštećenje srca \\
\hline heat detector & detektor toplote \\
\hline ignition source & izvor paljenja \\
\hline incidence rate & stopa incidencije \\
\hline injury analysis & analiza povrede \\
\hline job analysis & analiza posla \\
\hline knee injury & povreda kolena \\
\hline labour inspection & inspekcija rada \\
\hline labour inspector & inspektor rada \\
\hline leakage detector & detektor curenja \\
\hline light intensity & intenzitet svetlosti \\
\hline lighting conditions & uslovi osvetljenja \\
\hline loudness level & jačina zvuka \\
\hline luminance contrast & kontrast osvetljenosti \\
\hline machine damage & oštećenje mašine \\
\hline mine ventilation & ventilacija rudnika \\
\hline neighbourhood protection & zaštita okoline \\
\hline noise control & kontrola buke \\
\hline noise intensity & intenzitet buke \\
\hline noise level & nivo buke \\
\hline noise reduction & umanjenje buke \\
\hline noise source & izvor buke \\
\hline
\end{tabular}

TABLE 4: $\quad$ ENGLISH N + N SYNTACTIC STRUCTURES AND THEIR SERBIAN TRANSLATION EQUIVALENTS ( $\mathrm{N}+$ NOUN IN GENITIVE) 


\begin{tabular}{|c|c|}
\hline observation period & period posmatranja \\
\hline oxygen deficiency & nedostatak kiseonika \\
\hline power cords & kablovi napajanja \\
\hline pressure reducer & reduktor pritiska \\
\hline pressure regulator & regulator pritiska \\
\hline productivity loss & gubitak produktivnosti \\
\hline prohibition sign & znak zabrane \\
\hline protection factor & faktor zaštite \\
\hline protection system & sistem zaštite \\
\hline radiation exposure & izloženost zračenju \\
\hline radiation monitoring & monitoring zračenja \\
\hline risk assessment & procena rizika \\
\hline risk factors & faktori rizika \\
\hline risk management & upravljanje rizikom \\
\hline risk prevention & prevencija rizika \\
\hline safety engineer & inženjer bezbednosti \\
\hline safety inspection & inspekcija bezbednosti \\
\hline safety policy & politika bezbednosti \\
\hline safety programme & program bezbednosti \\
\hline safety standard & standardi bezbednosti \\
\hline smoke detector & detektor dima \\
\hline sound insulation & izolacija zvuka \\
\hline sound intensity & intenzitet zvuka \\
\hline sound level & nivo zvuka \\
\hline task analysis & analiza zadatka \\
\hline tolerance test & test izdržljivosti \\
\hline unemployment rate & stopa nezaposlenosti \\
\hline vibration damper & prigušivač vibracija \\
\hline vibration isolator & izolator vibracija \\
\hline waste disposal & odlaganje otpada \\
\hline
\end{tabular}

TABLE 4: $\quad$ ENGLISH N + N SYNTACTIC STRUCTURES AND THEIR SERBIAN TRANSLATION EQUIVALENTS ( $\mathrm{N}+$ Noun IN GENITIVE) 
Collection of Papers of the Faculty of Philosophy L(3)/2020

\begin{tabular}{|l|l|}
\hline water quality & kvalitet vode \\
\hline worker safety & bezbednost radnika \\
\hline \hline
\end{tabular}

TABLE 4: ENGLISH N + N SYNTACTIC STRUCTURES AND THEIR SERBIAN TRANSLATION EQUIVALENTS $(\mathrm{N}+$ NOUN IN GENITIVE)

\begin{tabular}{|l|l|}
\hline \multicolumn{1}{|c|}{ ENGLISH N + N SYNTACTIC STRUCTURES } & SERBIAN TRANSLATION EQUIVALENT (ADJ + N) \\
\hline climate changes & klimatske promene \\
\hline ear muffs & zaštitne slušalice \\
\hline exhaust system & izduvni sistem \\
\hline fire alarm & protivpožarni alarm \\
\hline first aid & prva pomoć \\
\hline health insurance & zdravstveno osiguranje \\
\hline health surveillance & zdravstveni nadzor \\
\hline labour force & radna snaga \\
\hline mental fatigue & mentalni zamor \\
\hline mental health & mentalno zdravlje \\
\hline safety clothing & zaštitna odeća \\
\hline safety footwear & zaštitna obuća \\
\hline safety glass & sigurnosno staklo \\
\hline safety glasses & zaštitne naočare \\
\hline shift work & smenski rad \\
\hline work overload & radno preopterećenje \\
\hline \hline
\end{tabular}

TABLE 5: ENGLISH N+N SYNTACTIC STRUCTURES AND THEIR SERBIAN TRANSLATION EQUIVALENTS (ADJ + N)

\begin{tabular}{||l|l||}
\hline \multicolumn{1}{|c|}{ ENGLISH N + N SYNTACTIC STRUCTURES } & SERBIAN TRANSLATION EQUIVALENT (N + PP) \\
\hline accident hazard & opasnost od akcidenta \\
\hline accident risk & rizik od nezgode \\
\hline breathing mask & maska za disanje \\
\hline calibration error & greška u kalibraciji \\
\hline
\end{tabular}

TABLE 6: ENGLISH N + N SYNTACTIC STRUCTURES AND THEIR SERBIAN TRANSLATION EQUIVALENTS $(\mathrm{N}+\mathrm{PP})$ 


\begin{tabular}{|c|c|}
\hline compensation claim & zahtev za kompenzaciju \\
\hline dust blouse & bluza za zastitu od prašine \\
\hline dust filter & filter za prašinu \\
\hline dust mask & maska protiv prašine \\
\hline ear plugs & čepovi za uši \\
\hline ear protector & štitnik za uši \\
\hline emergency exit & izlaz u slučaju opasnosti \\
\hline emergency plan & plan za hitne slučajeve \\
\hline emergency procedure & procedura u hitnim slučajevima \\
\hline explosion hazard & opasnost od eksplozije \\
\hline explosion protection & zaštita od eksplozije \\
\hline eye protector & zaštitnik za oko \\
\hline face shield & štitnik za lice \\
\hline fire extinguishant & sredstvo za gašenje požara \\
\hline fire extinguisher & aparat za gašenje požara \\
\hline fire hazard & opasnost od požara \\
\hline fire protection & zaštita od požara \\
\hline fire risks & rizici od požara \\
\hline hair net & mrežica za kosu \\
\hline hand guard & štitnik za ruke \\
\hline head protection & zaštita za glavu \\
\hline health hazard & opasnost po zdravlje \\
\hline radiation injury & povreda od zračenja \\
\hline safety hazards & opasnosti po zdravlje \\
\hline safety training & obuka iz bezbednosti \\
\hline testing laboratory & laboratorija za testiranje \\
\hline ventilation shaft & otvor za ventilaciju \\
\hline welding mask & maska za zavarivanje \\
\hline work accident & nezgoda na radu \\
\hline workplace conditions & uslovi na radnom mestu \\
\hline workplace hazards & opasnosti na radnom mestu \\
\hline
\end{tabular}

TABLE 6: ENGLISH $\mathrm{N}+\mathrm{N}$ SYNTACTIC STRUCTURES AND THEIR SERBIAN TRANSLATION EQUIVALENTS $(\mathrm{N}+\mathrm{PP})$ 


\begin{tabular}{|l|l|}
\hline workplace injury & povreda na radnom mestu \\
\hline workplace stress & stres na radu \\
\hline
\end{tabular}

TABLE 6: ENGLISH N + N SYNTACTIC STRUCTURES AND THEIR SERBIAN TRANSLATION EQUIVALENTS $(\mathrm{N}+\mathrm{PP})$

ЈЕЛЕНА Д. РАЈОВИЋ

ВИСОКА ТЕХНИЧКА ШКОЛА СТРУКОВНИХ СТУДИЈА

УРОШЕВАЦ СА ПРИВРЕМЕНИМ СЕДИШТЕМ У ЛЕПОСАВИТУ

МИЛИЦА М. СПАСИЋ СТОЈКОВИЋ

АКАДЕМИЈА СТРУКОВНИХ СТУДИЈА ЈУЖНА СРБИЈА

ОДСЕК ЗА ПОСЛОВНЕ СТУДИЈЕ БЛАЦЕ

РЕЗИМЕ

\section{СИНТАКСИЧКА КОНСТРУКЦИЈА ИМЕНИЦА+ИМЕНИЦА \\ У ЕНГЛЕСКОМ ЈЕЗИКУ СТРУКЕ \\ И ЊЕНИ ПРЕВОДНИ ЕКВИВАЛЕНТИ}

Енглески језик струке намењен је онима који енглески језик користе у професионалне сврхе и може се дефинисати у погледу употребе вокабулара и синтаксе. Сврха овог истраживања је да испитамо да ли постоји структурално слагање између синтаксичких структура које се састоје од две именице [именица+именица] у енглеском језику заштите на раду и њихових преводних еквивалената у српском језику. Након што смо резултате истраживања сузили на око пет хиљада примера и поређали их по учесталости појављивања у корпусу, узорак од око сто седамдесет примера издвојен је и преведен на српски језик. Анализа је показала да можемо разликовати три типа српских преводних еквивалената, али да ниједан он њих није структурно идентичан енглеским синтаксичким структурама које се састоје од две именице [именица+именица].

КљУчнЕ РЕчи: енглески језик струке; синтаксичке структуре; заштита на раду; српски језик; енглески језик.

Овај чланак је објављен и дистрибуира се под лиценцом Creative Commons Ауторство-Некомерцијално Међународна 4.0 (СC BY-NC 4.0 | https://creativecommons.org/licenses/by-nc/4.0/). This paper is published and distributed under the terms and conditions of the Creative Commons Attribution-NonCommercial International 4.0 licence (CC BY-NC 4.0 | https://creativecommons.org/licenses/by-nc/4.0/). 